\title{
Dietary History
}

National Cancer Institute

\section{Source}

National Cancer Institute. Dietary History. NCI Thesaurus. Code C17994.

A history of daily food intake. 